\title{
The Influence of Polychlorinated Biphenyls Contamination on Soil Protein Expression
}

\author{
Xi Zhang, ${ }^{1}$ Feng Li, ${ }^{1,2}$ Tingting Liu, ${ }^{1}$ Cheng Peng, ${ }^{1}$ Dechao Duan, ${ }^{1}$ Chen Xu, ${ }^{1}$ \\ Shenhai Zhu, ${ }^{1}$ and Jiyan Shi ${ }^{1}$ \\ ${ }^{1}$ Institute of Environmental Science and Technology, Zhejiang University, Hangzhou, Zhejiang 310058, China \\ ${ }^{2}$ College of Materials and Environmental Engineering, Hangzhou Dianzi University, Hangzhou, Zhejiang 310018, China \\ Correspondence should be addressed to Jiyan Shi; shijiyan@zju.edu.cn
}

Received 7 October 2013; Accepted 30 October 2013

Academic Editors: J. Artiola and Z. He

Copyright (C) 2013 Xi Zhang et al. This is an open access article distributed under the Creative Commons Attribution License, which permits unrestricted use, distribution, and reproduction in any medium, provided the original work is properly cited.

Polychlorinated biphenyls (PCBs) are typical representative of chlorinated organic pollutants. Given the toxicity of PCBs, there is an urgent need to select an appropriate indicator to monitor their biological effects on soil ecosystems. For this purpose, we investigated the impacts of PCBs on soil protein and the potential of using protein as a biological indicator to assess soil contamination due to PCBs. This study demonstrated that soil protein concentration and expression were negatively affected by PCBs. In addition, significantly $(P<0.01)$ negative correlation was observed between protein concentration and PCBs. Subsequently, protein size distribution separated by SDS-PAGE revealed that with the increase in PCBs concentration there are less large molecular weight proteins and more low molecular weight proteins $(<40 \mathrm{kD})$. Consequently, soil protein level has the potential to be an indicator of soil contamination, and these low molecular weight proteins have significant meaning for getting insight into the ecological effects of PCBs on the soil environment.

\section{Introduction}

Chlorinated organic chemicals probably constitute half of the environmental organic pollutants problems worldwide. Polychlorinated biphenyls (PCBs) almost all come from anthropogenic origin (mostly from electronic and electrical waste, called e-waste, and recycling activity) and are one of the two chlorinated chemical classes that cause the most extensive environmental pollution $[1,2]$. Since they are highly resistant to degradation, with very low solubility in water and being combined with soil organic matter, they remain in the soil for many years. Furthermore, because they are lipophilic in nature, they are passed through the food chain and are bioaccumulated in organisms. Consequently, PCBs have great negative effects on plants and microorganisms; they harm the whole soil biosphere, finally threatening human health [2-6]. Given the toxicity of PCBs, there is an urgent need to monitor their biological effects on the soil ecosystems.

The physical, chemical, and biological indicators are three important properties for monitoring and assessing soil con- tamination. Biological indicators, especially enzyme activity, for is sensitivity to the changes in pollutants, is closely related to nutrient cycles and easy to determinate and has become the most widely used property to monitor soil function and health [7-9]. Although enzyme activity has these advantages, much literature has indicated that contaminated soil is a complex system, and the interaction of pollutants, especially organic pollutants, with soil is complicated. Thus, diverse types of soil, different pollutants, and concentrations have various effects on a certain enzyme activity. Consequently, the change in enzyme activity may be inconsistent with the change in pollutants and fails to reflect the actual toxicity of pollutants in soil in some situations, which have put their reliability as a possible indicator to monitor soil pollution in question [8, 10-14]. Enzyme activity needs other biological indicators to supplement it.

Currently, the emergence of soil proteomics could offer us a new perspective to solve the problem [15]. Proteins are the major actors in organism metabolism process, and they fall into a variety of categories; for example, enzymes are 
TABLE 1: Selected soil physicochemical properties, PCBs concentration, and heavy metals content.

\begin{tabular}{lcccccccccc}
\hline Soil sample & CK & A & B & C & D & E & F & G & H \\
\hline pH & 5.72 & 5.31 & 6.89 & 5.10 & 5.88 & 5.59 & 5.52 & 5.66 & 5.74 & 5.79 \\
Soil organic matter $(\%)$ & 9.15 & 9.06 & 9.03 & 8.49 & 8.63 & 8.89 & 7.42 & 8.07 & 8.02 & 6.89 \\
PCBs content $\left(\mu \mathrm{g}^{-1} \mathrm{~kg}^{-1}\right)$ & 12 & 313 & 257 & 238 & 229 & 218 & 194 & 177 & 109 & 92 \\
Cr content $\left(\mathrm{mg} \cdot \mathrm{kg}^{-1}\right)$ & 59.92 & 54.72 & 53.57 & 60.75 & 49.85 & 66.77 & 57.50 & 60.80 & 53.05 & 51.25 \\
Cu content $\left(\mathrm{mg} \cdot \mathrm{kg}^{-1}\right)$ & 69.52 & 73.70 & 59.92 & 77.62 & 63.72 & 54.65 & 68.47 & 76.40 & 69.35 & 56.47 \\
Pb content $\left(\mathrm{mg} \cdot \mathrm{kg}^{-1}\right)$ & 115.17 & 119.60 & 117.37 & 101.75 & 118.02 & 97.40 & 123.35 & 105.32 & 131.00 & 116.15 \\
Zn content $\left(\mathrm{mg} \cdot \mathrm{kg}^{-1}\right)$ & 158.87 & 159.20 & 140.77 & 154.05 & 151.92 & 142.37 & 165.52 & 149.87 & 162.10 & 139.27 \\
\hline
\end{tabular}

proteins with a catalytic function. Proteins work together to complete various biological functions. Soil proteins mainly come from microorganisms as well as from flora and fauna tissue. Microbial community structure, biomass, and microbial status often determine the synthesis level of soil proteins. Therefore, any modification of microbial composition caused by environmental changes, such as contamination and agricultural practices, could be reflected in the level of soil protein concentration and its expression [16]. Soil proteomics studies aim to investigate the spatial and temporal changes of proteins extracted from soils because proteins are the functional components of microbial genomic expression products. Such studies more conclusively explore the ecological functions of soil microbes and their roles in soil pollutants transformation and degradation [17-19]. Consequently, it has great potential to be a valid indicator for soil pollution.

Nowadays, soil proteomics are predominantly used in the geobiochemistry cycle [20-22] and the rhizosphere soil microecosystem $[23,24]$. However, there is little research on monitoring contaminated soil, and the existing studies were all carried out under controlled conditions [16, 25]. Unlike a controlled laboratory, natural soil is a complicated ecosystem, and various factors have integrated impacts on the transformation and degradation of pollutants as well as the structure of the microorganism community. Consequently, we were interested in examining the profile modification of soil proteins under PCBs stress and discussing whether proteins profile can be a proper indicator for natural soil pollution.

The first objective of the work was to study the variation in protein concentration of soil contaminated by PCBs. The second objective of the work was to determine whether there are differences in protein expression existing between proteins extracted from PCBs contaminated soils and uncontaminated control.

\section{Materials and Methods}

2.1. Research Area and Sampling. In this study, agriculture land in Taizhou, Zhejiang Province, China, which was seriously contaminated by PCBs was chosen as the experimental subject. Soil samples were collected from nine sites which were marked from A to I, respectively, according to the decreasing concentration of PCBs. An agriculture field which was outside the polluted area and has a similar soil type and utilization to the contaminated land was chosen as the reference site, and the soil sample collected from it was marked "CK." Each sample was composed of five soil cores $5 \mathrm{~cm}$ in diameter and $15 \mathrm{~cm}$ in depth (approximately $1 \mathrm{~kg}$ ) and was homogenized thoroughly.

2.2. Sample Treatment and Analysis. Part of the soil samples was freeze-dried prior to PCBs analysis and protein extraction. Part of the soil samples was air-dried under cool condition (about $20^{\circ} \mathrm{C}$ ) and stored at $4^{\circ} \mathrm{C}$ for soil organic matter (SOM), $\mathrm{pH}$, and heavy metals determination. All the soil samples were sieved to pass through a $0.25 \mathrm{~mm}$ sieve.

Soil $\mathrm{pH}$ was determined in distilled water, using a $\mathrm{pH}$ meter (Orion-5-Star, Thermo), at a ratio (soil : water) of $1: 2.5$ $(\mathrm{w} / \mathrm{v})$. Soil was heated at $105^{\circ} \mathrm{C}$ for $12 \mathrm{~h}$ and then combusted at $550^{\circ} \mathrm{C}$ overnight to measure organic matter content [26]. The samples were digested using the method described by Tang et al. [6]. Dry sample (0.2 g) was weighed and digested with a mixture of nitric acid $\left(\mathrm{HNO}_{3}\right)$, hydrofluoric acid $(\mathrm{HF})$, and perchloric acid $\left(\mathrm{HClO}_{4}\right)$. Concentrations of $\mathrm{Cr}, \mathrm{Cu}, \mathrm{Pb}$, and $\mathrm{Zn}$ were measured by flame atomic absorption spectrometry (MKIL-M6, Thermo).

PCBs were extracted from soil by Soxhlet procedure [27]; then the concentrated extract was cleaned up by a Florisil/anhydrous sodium sulphate column and eluted with $100 \mathrm{~mL}$ hexane. Finally, the concentrations of PCBs were quantified by a gas chromatograph equipped with a ${ }^{63} \mathrm{Ni}$ electron capture detector (7890, Agilent) [6]. The procedure was performed under quality control. PCB 209 was added to detect the recoveries. The recoveries of surrogate standards for PCBs determinations were in the range of $75.3 \sim 105.0 \%$. In this paper, the final concentrations of PCBs in soils were not corrected with recoveries.

Selected soil physicochemical properties, PCBs concentration, and heavy metals content are shown in Table 1. All soil samples were mildly acidic and $\mathrm{pH}$ ranged from 5.10 to 6.89 . The soil samples have a high SOM content of between $6.89 \%$ and $9.15 \%$. The high SOM content might be due to the use of organic fertilizer in the field. Cr concentrations were below the natural background as defined by the Chinese Environmental Quality Standards for Soil. $\mathrm{Cu}$ concentrations slightly exceeded the Grade II value of soil quality standards of the State Environmental Protection Administration of China (SEPA) $\left(50 \mathrm{mg} \cdot \mathrm{kg}^{-1}\right)$. Furthermore, $\mathrm{Pb}$ and $\mathrm{Zn}$ concentrations were below the Grade II value of soil quality standards from SEPA which are $250 \mathrm{mg} \cdot \mathrm{kg}^{-1}$ and $200 \mathrm{mg} \cdot \mathrm{kg}^{-1}$, respectively. According to SEPA, the Grade II is 


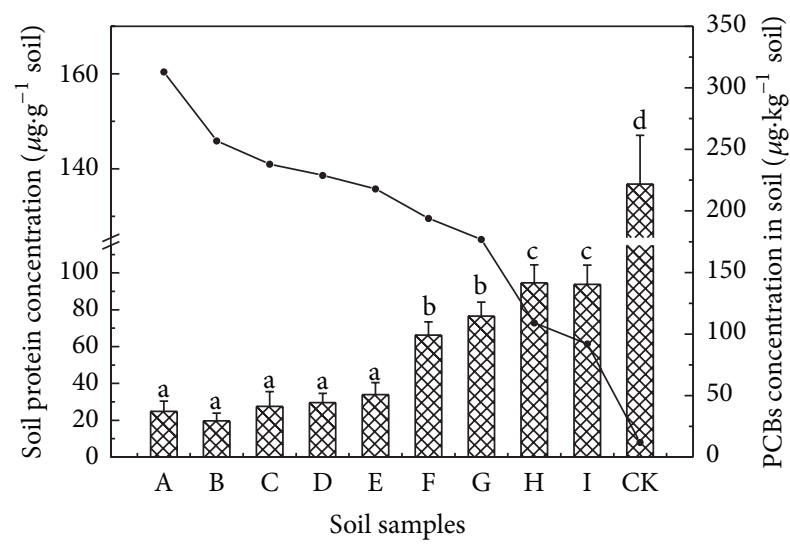

$\square \times$ Soil protein concentration -•- PCBs concentration in soil

Figure 1: The effect of PCBs on soil protein content. Note: different letters above the columns indicate significant differences $(P<0.05)$.

the marginal value for soil health. Consequently, the influence of heavy metals on soil ecology was not considered in this study.

Currently, there are no environmental standards for soil PCBs concentration in China. Nevertheless, the concentrations of PCBs in soils from contaminated sites were all higher than the allowable level of $60 \mu \mathrm{g} \cdot \mathrm{kg}^{-1}$ for PCBs in ambient soil, regulated by the former USSR Ministry of Health in $1991[6]$.

2.3. Soil Protein Extraction. The citrate-SDS sequential extraction method $[23,24]$ was used to extract soil protein. Specifically, $3 \mathrm{~g}$ of dried soil was mixed with $15 \mathrm{~mL}$ of $0.25 \mathrm{M}$ citrate buffer ( $\mathrm{pH} 8.0)$, and the homogenate was shaken at $1200 \mathrm{rpm}$ in room temperature for $4 \mathrm{~h}$. Then, the suspension was centrifuged for $15 \mathrm{~min}$ at $15000 \times \mathrm{g}$ and $4^{\circ} \mathrm{C}$ and filtered through filter paper $(30 \sim 50 \mu \mathrm{m})$. Afterwards, the soil was extracted by $15 \mathrm{~mL}$ SDS buffer, which contained $1.25 \%(\mathrm{w} / \mathrm{v})$ SDS, $0.1 \mathrm{M}$ Tris- $\mathrm{HCl}$ (pH 6.8), and $20 \mathrm{mM}$ dithiothreitol (DTT). This SDS soil mixture was shaken for $1 \mathrm{~h}$ at $1200 \mathrm{rpm}$ and room temperature, and then it was centrifuged for $15 \mathrm{~min}$ at $15000 \times \mathrm{g}$ and $4^{\circ} \mathrm{C}$. For protein recovery, both the citrate extract and the SDS extract were mixed with buffered phenol ( $\mathrm{pH} 8.0)$ at a volume ratio (extract: phenol) of $3: 1$ and centrifuged at $15000 \times \mathrm{g}$ and $4^{\circ} \mathrm{C}$ for $30 \mathrm{~min}$. After centrifugation, the phenol phase was precipitated at $-20^{\circ} \mathrm{C}$ overnight with five volumes of cold $0.1 \mathrm{M}$ ammonium acetate dissolved in methanol. Proteins were recovered by centrifugation at $20000 \times \mathrm{g}$ and $4^{\circ} \mathrm{C}$ for $20 \mathrm{~min}$. The pellets were washed once with cold methanol and twice with cold acetone, and then they were air-dried for further use.

\subsection{Protein Content Determination and Protein Separation.} The protein pellets were solubilized in $500 \mu \mathrm{L}$ lysis buffer which contained $9 \mathrm{M}$ urea, $4 \%$ w/v CHAPS, $1 \%$ w/v DTT, $0.5 \%$ ampholyte, and $1 \mathrm{mM}$ PMSF. The concentration of protein in the supernatant was determined by Bradford method [28] and the protein was stored at $-70^{\circ} \mathrm{C}$.
Samples of the extracted proteins were added to an equal volume of loading buffer, which contained $100 \mathrm{mM}$ Tris$\mathrm{HCl}(\mathrm{pH} 6.8), 4 \%(\mathrm{w} / \mathrm{v})$ SDS, $20 \%$ glycerol, $0.5 \%(\mathrm{w} / \mathrm{v})$ bromophenol blue, and $100 \mathrm{mMDTT}$, and then they were heated in water at $95^{\circ} \mathrm{C}$ for $5 \mathrm{~min}$ prior to SDS-PAGE [16]. Subsequently, discontinuous SDS-PAGE was performed using the Mini-PROTEAN 3 Electrophoresis Cell (Bio-Rad) with a $4 \%$ stacking gel and a $12 \%$ separating gel. The process was run at a constant $75 \mathrm{~V} /$ gel through the stacking gel and a constant $150 \mathrm{~V} /$ gel through the separating gel. A prestained protein ladder (approximately 10 to $170 \mathrm{kDa}$, Fermentas) was loaded as a molecular weight marker, and each lane was loaded with the same quantity of protein. After separation, the gels were stained by silver staining [29] for further comparison.

2.5. Data Analysis. All measurements of soil $\mathrm{pH}$, levels of organic matter, heavy metals, and proteins concentration were performed in triplicate. All of the values reported are the average of three determinations. All of the statistical analyses were performed using SPSS software, version 16.0. One-way analysis of variance (ANOVA) was used for statistical comparisons, and the Pearson coefficient was used for correlation analysis. A value of $P<0.05$ was considered statistically significant.

\section{Results and Discussions}

During the study, the response of soil protein to PCBs stress was investigated, and the results are shown in Figures 1 and 2. The reference site has significantly $(P<0.05)$ greater amounts of protein than PCBs contaminated soil. The quantity of soil proteins was significantly negatively correlated with PCBs concentration $(r=-0.889, P<0.01)$ (Figure 1).

The protein profiles are shown in Figure 2. The results indicate that there is no discernable difference between different samples extracted by citrate and the bands are almost all located between 40 and $70 \mathrm{kD}$. Additionally, although the SDS buffer extracts showed similar protein patterns in different soil samples, the expression of some proteins was significantly different. Compared with the contaminated soil samples, the uncontaminated samples had more abundant proteins overall. In the contaminated site, with the increase in PCBs concentration $(\mathrm{I} \rightarrow \mathrm{A})$, there were fewer large molecular weight $(40 \sim 130 \mathrm{kD})$ proteins and more low molecular weight $(<40 \mathrm{kD})$ proteins. Therefore, these low molecular weight proteins were largely agglomerated and produced dark areas on the gels.

The amount of soil protein decreasing dramatically in contaminated soil might be due to the fact that the growth of most microorganisms was constrained by the existence of PCBs [30]. Furthermore, the changes in protein pattern might indicate that the community structure of soil microorganisms and their physiological activities were modified significantly under pollutants stress [15]. These low molecular weight proteins could be related to the presence of PCBs and could be a microbial response to organic pollutants. A study of Correa et al. [31] indicated that soil samples exposed to PCBs have lower bacterial abundance compared with nonexposed 


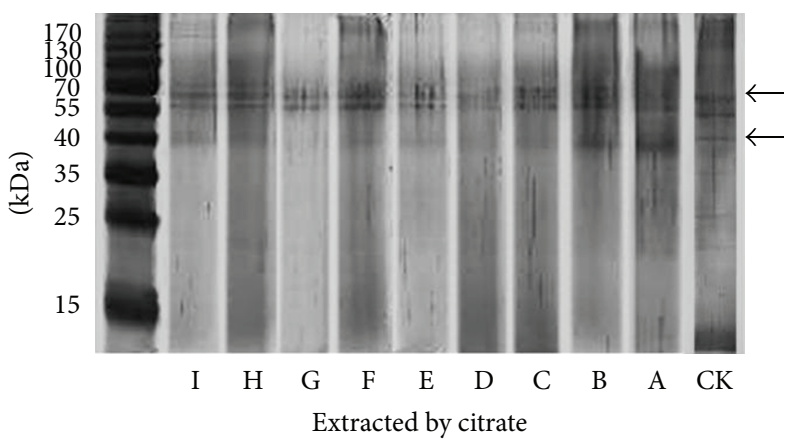

(a)

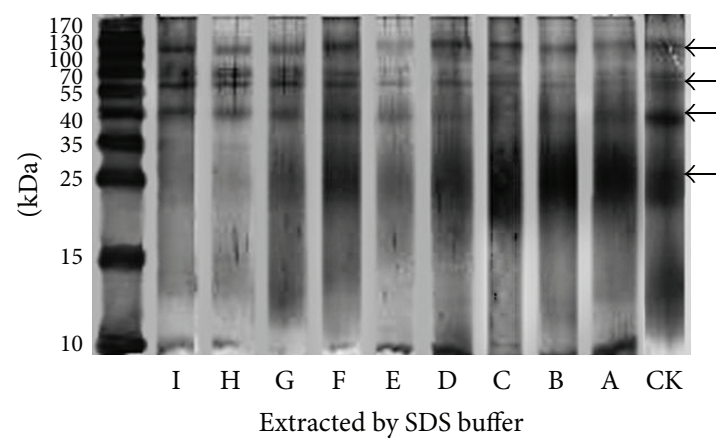

(b)

FIgURE 2: The effect of PCBs on soil protein expression.

soil and the amount of Proteobacteria and Actinobacteria increased greatly. They used RT-PCR to measure the quantification of biphenyl dioxygenase $(b p h)$ genes which showed that the genes significantly increased in contaminated soil. $B p h$ genes could encode polypeptide and small molecular proteins (about $30 \mathrm{kD}$ ) that relate to the degradation of PCBs. For example, biphenyl 2,3-dioxygenases; cis-2,3-dihydro-2,3dihydroxybiphenyl; 2,3-dihydroxybiphenyl-1,2-dioxygenase; and glutathione-s-transferase are all encoded by $b p h$ genes and crucial to the ring cleavage and dechloridation of PCBs [32-37]. Alternatively, some microbes were not tolerant strains and died under PCBs stress. Then, the cells were lysed and proteins were released into the environment. Finally, these proteins were degraded into small molecular material [16]. Moreover, it was interesting to note that there were also a lot of low molecular weight proteins in the uncontaminated sample and their composition and functions were needed to be characterized. Consequently, further work is needed to identify these low molecular proteins. It will help us to gain a better understanding if these proteins participate in the degradation of PCBs and see if certain proteins could be a reliable indicator to monitor the response of microbes to pollutants and assess the degree of soil contamination.

Although these results indicate that protein seems to have a great potential to be an indicator for soil contamination, its reliability still needs more studies since Bradford method is easily affected by humic substances present in protein solution [38]. Therefore, further discussions about the interaction between protein and soil constituents are needed.

Granting that SDS-PAGE is useful for monitoring changes in microbial metabolism under pollutants stress, it still has drawbacks in practice. The approach is easily interfered by impurities coextracted with the soil protein, mainly by humic substances [15]. The protein mixed with organic matter was not easily separated by SDS-PAGE. Also, relatively low abundance of protein may not be identified by SDS-PAGE [16]. Taking this study as an example, SDS-PAGE profiles have a dark background and are smeared at the bottom of SDSPAGE gel, which make the accuracy and reliability of the analysis questionable. Consequently, the molecular technique used in this study has much room for further improvement and more work is required to develop effective extraction methods for soil protein.

No single technique can provide a comprehensive depiction of the soil microbial situation. Therefore, soil microbial activity and diversity are difficult to elucidate. To obtain better understanding of soil microbial ecology, we need to integrate different methods to create a comprehensive analysis.

\section{Conclusion}

Our study demonstrated that PCBs have a significant negative effect on soil protein. Soil protein was significantly negatively correlated to PCBs concentration. Furthermore, the soil protein expression was similar in different soils, but a large quantity of presumably low molecular weight protein was observed only in PCBs contaminated soil. Based on the research described in this paper, we can conclude that the soil protein level has potential to be an indicator of soil contamination.

In this paper, we just discussed the potential of soil protein as an indicator for soil contamination. However, soil protein as an assessment indicator requires a much larger study in different soils and pollutant types before wide use. Currently, soil proteomics is still in its infancy stage. Consequently, more work needs to be done to gain a high quality profile of protein expression, such as soil protein extraction, separation, identification, and so on. Only in this way can we detect the stress protein and make the application of protein in monitoring soil contaminants valid.

\section{Conflict of Interests}

The authors declare that there is no conflict of interests regarding the publication of this paper.

\section{Acknowledgments}

This work was financially supported by the Science Foundation of Postdoctor of China (20100471714 and 201104718), National Natural Science Foundation for the Youth of China (21007055), and Program for New Century Excellent Talents in University (NCET-11-0455). 


\section{References}

[1] G. W. Gribble, "The natural production of chlorinated compounds," Environmental Science and Technology, vol. 28, no. 7, pp. 310A-319A, 1994.

[2] J. M. Tiedje, J. F. I. I. Quensen, J. Chee-Sanford, J. P. Schimel, and S. A. Boyd, "Microbial reductive dechlorination of PCBs," Biodegradation, vol. 4, no. 4, pp. 231-240, 1993.

[3] J. Borja, D. M. Taleon, J. Auresenia, and S. Gallardo, "Polychlorinated biphenyls and their biodegradation," Process Biochemistry, vol. 40, no. 6, pp. 1999-2013, 2005.

[4] K. Furukawa and H. Fujihara, "Microbial degradation of polychlorinated biphenyls: biochemical and molecular features," Journal of Bioscience and Bioengineering, vol. 105, no. 5, pp. 433449, 2008.

[5] S. H. Safe, "Polychlorinated biphenyls (PCBs): environmental impact, biochemical and toxic responses, and implications for risk assessment," Critical Reviews in Toxicology, vol. 24, no. 2, pp. 87-149, 1994.

[6] X. Tang, C. Shen, D. Shi et al., "Heavy metal and persistent organic compound contamination in soil from Wenling: an emerging e-waste recycling city in Taizhou area, China," Journal of Hazardous Materials, vol. 173, no. 1-3, pp. 653-660, 2010.

[7] W. T. Frankenberger Jr. and W. A. Dick, "Relationships between enzyme activity and microbial growth and activity indices in soil," Soil Science Society of America Journal, vol. 47, no. 5, pp. 945-951, 1983.

[8] E. Kandeler, C. Kampichler, and O. Horak, "Influence of heavy metals on the functional diversity of soil microbial communities," Biology and Fertility of Soils, vol. 23, no. 3, pp. 299-306, 1996.

[9] M. Wang, B. Markert, W. Shen, W. Chen, C. Peng, and Z. Ouyang, "Microbial biomass carbon and enzyme activities of urban soils in Beijing," Environmental Science and Pollution Research, vol. 18, no. 6, pp. 958-967, 2011.

[10] M. Baruah and R. R. Mishra, "Effect of herbicides butachlor, 2,4$\mathrm{D}$ and oxyfluorfen on enzyme activities and $\mathrm{CO}_{2}$ evolution in submerged paddy field soil," Plant and Soil, vol. 96, no. 2, pp. 287-291, 1986.

[11] P. Doelman and L. Haanstra, "Effect of lead on soil respiration and dehydrogenase activity," Soil Biology and Biochemistry, vol. 11, no. 5, pp. 475-479, 1979.

[12] G. W. McCarty, R. Siddaramappa, R. J. Wright, E. E. Codling, and G. Gao, "Evaluation of coal combustion byproducts as soil liming materials: their influence on soil $\mathrm{pH}$ and enzyme activities," Biology and Fertility of Soils, vol. 17, no. 3, pp. 167172, 1994.

[13] C. Trasar-Cepeda, M. C. Leirós, S. Seoane, and F. Gil-Sotres, "Limitations of soil enzymes as indicators of soil pollution," Soil Biology and Biochemistry, vol. 32, no. 13, pp. 1867-1875, 2000.

[14] K. Chander and P. C. Brookes, "Is the dehydrogenase assay invalid as a method to estimate microbial activity in coppercontaminated soils?" Soil Biology and Biochemistry, vol. 23, no. 10, pp. 909-915, 1991.

[15] F. Bastida, J. L. Moreno, C. Nicolás, T. Hernández, and C. García, "Soil metaproteomics: a review of an emerging environmental science. Significance, methodology and perspectives," European Journal of Soil Science, vol. 60, no. 6, pp. 845-859, 2009.

[16] I. Singleton, G. Merrington, S. Colvan, and J. S. Delahunty, "The potential of soil protein-based methods to indicate metal contamination," Applied Soil Ecology, vol. 23, no. 1, pp. 25-32, 2003.
[17] P.-A. Maron, L. Ranjard, C. Mougel, and P. Lemanceau, "Metaproteomics: a new approach for studying functional microbial ecology," Microbial Ecology, vol. 53, no. 3, pp. 486-493, 2007.

[18] P. Wilmes and P. L. Bond, “The application of two-dimensional polyacrylamide gel electrophoresis and downstream analyses to a mixed community of prokaryotic microorganisms," Environmental Microbiology, vol. 6, no. 9, pp. 911-920, 2004.

[19] P. Wilmes and P. L. Bond, "Metaproteomics: studying functional gene expression in microbial ecosystems," Trends in Microbiology, vol. 14, no. 2, pp. 92-97, 2006.

[20] S. Criquet, A. M. Farnet, and E. Ferre, "Protein measurement in forest litter," Biology and Fertility of Soils, vol. 35, no. 5, pp. 307-313, 2002.

[21] W. X. Schulze, G. Gleixner, K. Kaiser, G. Guggenberger, M. Mann, and E.-D. Schulze, "A proteomic fingerprint of dissolved organic carbon and of soil particles," Oecologia, vol. 142, no. 3, pp. 335-343, 2005.

[22] E. B. Taylor and M. A. Williams, "Microbial protein in soil: influence of extraction method and $\mathrm{C}$ amendment on extraction and recovery," Microbial Ecology, vol. 59, no. 2, pp. 390-399, 2010.

[23] S. Chen, M. C. Rillig, and W. Wang, "Improving soil protein extraction for metaproteome analysis and glomalin-related soil protein detection," Proteomics, vol. 9, no. 21, pp. 4970-4973, 2009.

[24] H.-B. Wang, Z.-X. Zhang, H. Li et al., "Characterization of metaproteomics in crop rhizospheric soil," Journal of Proteome Research, vol. 10, no. 3, pp. 932-940, 2011.

[25] D. Benndorf, G. U. Balcke, H. Harms, and M. von Bergen, "Functional metaproteome analysis of protein extracts from contaminated soil and groundwater," The ISME Journal, vol. 1, no. 3, pp. 224-234, 2007.

[26] E. Baath, A. Frostegaard, T. Pennanen, and H. Fritze, "Microbial community structure and $\mathrm{pH}$ response in relation to soil organic matter quality in wood-ash fertilized, clear-cut or burned coniferous forest soils," Soil Biology and Biochemistry, vol. 27, no. 2, pp. 229-240, 1995.

[27] C. Shen, Y. Chen, S. Huang et al., "Dioxin-like compounds in agricultural soils near e-waste recycling sites from Taizhou area, China: chemical and bioanalytical characterization," Environment International, vol. 35, no. 1, pp. 50-55, 2009.

[28] M. M. Bradford, "A rapid and sensitive method for the quantitation of microgram quantities of protein utilizing the principle of protein dye binding," Analytical Biochemistry, vol. 72, no. 1-2, pp. 248-254, 1976.

[29] J. X. Yan, R. Wait, T. Berkelman et al., "A modified silver staining protocol for visualization of proteins compatible with matrix-assisted laser desorption/ionization and electrospray ionization- mass spectrometry," Electrophoresis, vol. 21, pp. 3666-3672, 2000.

[30] L. Dušek and M. Tesařová, "Influence of polychlorinated biphenyls on microbial biomass and its activity in grassland soil," Biology and Fertility of Soils, vol. 22, no. 3, pp. 243-247, 1996.

[31] P. A. Correa, L. Lin, C. L. Just et al., "The effects of individual PCB congeners on the soil bacterial community structure and the abundance of biphenyl dioxygenase genes," Environment International, vol. 36, no. 8, pp. 901-906, 2010.

[32] K. Furukawa, "Biochemical and genetic bases of microbial degradation of polychlorinated biphenyls (PCBs)," The Journal of General and Applied Microbiology, vol. 46, no. 6, pp. 283-296, 2000 . 
[33] D. H. Pieper and M. Seeger, "Bacterial metabolism of polychlorinated biphenyls," Journal of Molecular Microbiology and Biotechnology, vol. 15, no. 2-3, pp. 121-138, 2008.

[34] M. Seeger, K. N. Timmis, and B. Hofer, "Bacterial pathways for the degradation of polychlorinated biphenyls," Marine Chemistry, vol. 58, no. 3-4, pp. 327-333, 1997.

[35] W.-R. Abraham, B. Nogales, P. N. Golyshin, D. H. Pieper, and K. N. Timmis, "Polychlorinated biphenyl-degrading microbial communities in soils and sediments," Current Opinion in Microbiology, vol. 5, no. 3, pp. 246-253, 2002.

[36] R. Blasco, M. Mallavarapu, R.-M. Wittich, K. N. Timmis, and D. H. Pieper, "Evidence that formation of protoanemonin from metabolites of 4-chlorobiphenyl degradation negatively affects the survival of 4-chlorobiphenyl-cometabolizing microorganisms," Applied and Environmental Microbiology, vol. 63, no. 2, pp. 427-434, 1997.

[37] O. Pelz, M. Tesar, R.-M. Wittich, E. R. B. Moore, K. N. Timmis, and W.-R. Abraham, "Towards elucidation of microbial community metabolic pathways: unravelling the network of carbon sharing in a pollutant-degrading bacterial consortium by immunocapture and isotopic ratio mass spectrometry," Environmental Microbiology, vol. 1, no. 2, pp. 167-174, 1999.

[38] P. Roberts and D. L. Jones, "Critical evaluation of methods for determining total protein in soil solution," Soil Biology and Biochemistry, vol. 40, no. 6, pp. 1485-1495, 2008. 

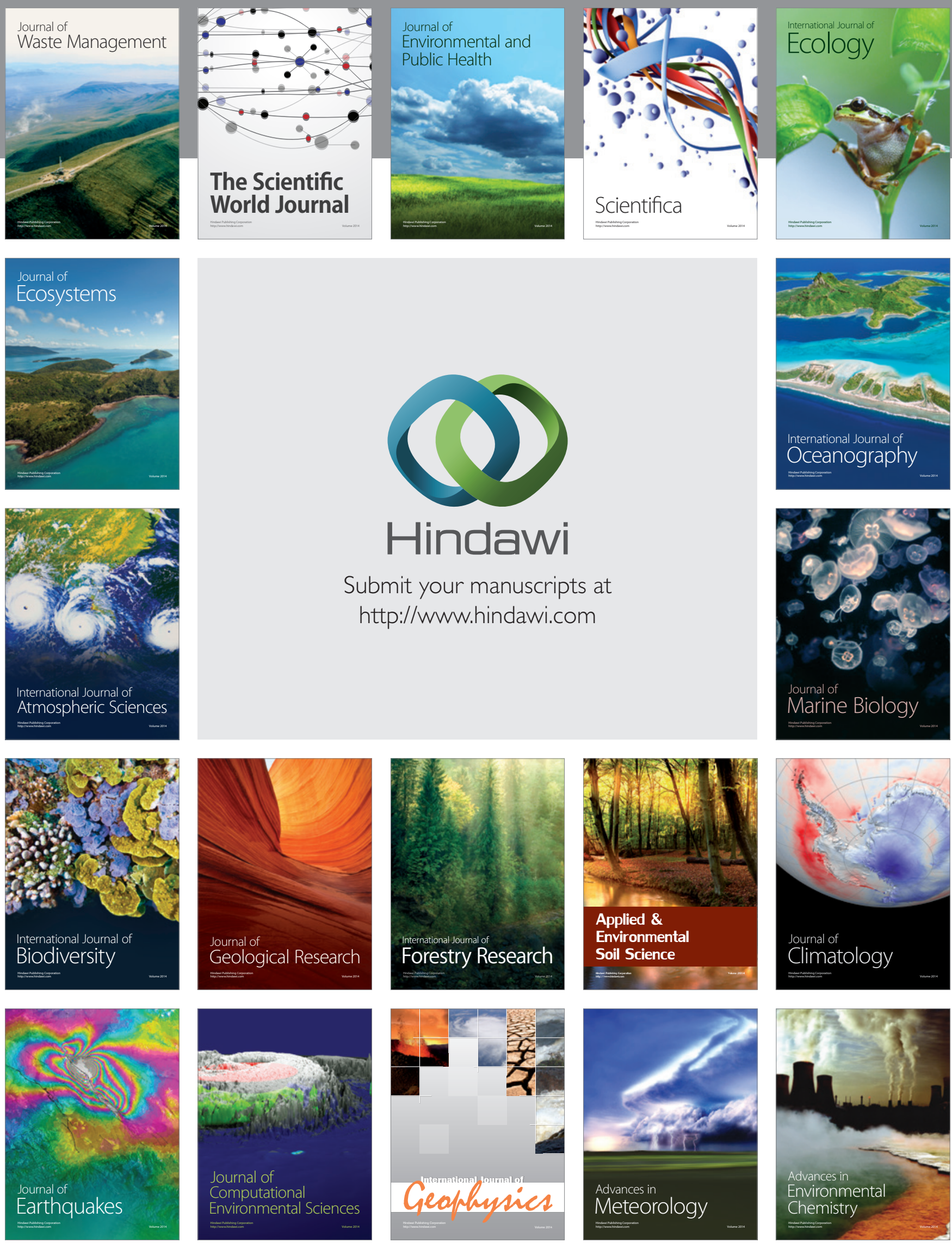